\title{
Wired Communication Problem
}

National Cancer Institute

\section{Source}

National Cancer Institute. Wired Communication Problem. NCI Thesaurus. Code C92131.

Communications problems between devices within a wired system. 